Paper

\title{
Good practices in honors education with examples to follow
}

\author{
Pierre van Eijl and Albert Pilot \\ Utrecht University, The Netherlands \\ Correspondence: p.j.vaneijl@uu.nl
}

Received: 12 November 2018; Accepted: 13 December 2018; Published: 7 January 2019

\begin{abstract}
Honors education offers students challenging experiences and teachers a laboratory for educational innovation. Successful innovations can stimulate other teachers to experiment and improve their educational practice. This requires that innovations become known to other teachers. For this reason, a project on good practices in honors education has been started in The Netherlands, where good practices in honors education of universities were described and published on a website of the Dutch Honors Network. Until now, 19 good practices are described, 17 from The Netherlands and two from the United States. Nine are selected for this issue. In this introductory paper, the good practice project and research about good practices are described. Different views and principles about honors education are discussed. A series of keywords to bridge the different views and the principles with the nine good practices published in this issue are presented. An analysis of the collected data of the good practices is carried out, followed by conclusions, discussions, and reflections. It appears that six good practices already led to innovations elsewhere in curricula.
\end{abstract}

Keywords: good practice, honors, higher education, transfer

\section{Start of the good practice project in the honors network}

The 'good practice project' started with the observation that, in many honors programs, there are good examples of innovative educational practices which can be a source of inspiration for other teachers. Good examples have been developed thanks to the favorable conditions in an honors program for a teacher to experiment and with students willing to take on a new challenge.

These good practices are only known to a small circle of people. If a teacher tells others about his or her experiences at an honors conference, more information from the good example can trickle down to others. It spreads even further if a good example is presented in a workshop and the participants experience that example. A visit to the class of the good 
practice can also help spread awareness but is not always easy to organize. To make good examples of honors education more widely known, they have been published by the Honors Network in The Netherlands on a website. On this website, examples of good honors education are posted according to a format (presented in Appendix A). Readers of this good practice can contact the teacher. In this project, we use a simple description of a good practice: 'a piece of honors education that functions, in the opinion of the teacher involved, so well for the students that it may be an inspiring example for others.'

Three questions were central in this project about good practices in honors education:

1. Is it possible to collect good practices in honors education via an honors network?

2. What are the characteristics of good practices in honors education as described by their teachers?

3. Do teachers of these good practices think these can be applied in other educational programs?

In this paper, the authors describe the project, the theoretical background, and provide an analysis of this set of good practices.

\section{Desirable characteristics of good practices}

Honors is often a laboratory of educational innovation (Wolfensberger, van Eijl \& Pilot, 2004; 2012) and a gold mine for innovative ideas. Innovation in education is often a difficult process, but 'a good example tends to be followed' and can inspire others.

We identified four desirable characteristics:

\section{The good practice should have the characteristics of a model}

According to Earl (1983), a good practice of a course (or activity) can function as a model in (re)designing a piece of education. This requires a description in which 'the typical pattern of steps or activities' of the good practice becomes clear for the reader. Bardach (2011) stresses the importance that the 'core' of the good practice (why and how it works) has to be clear when adapting it for another source in another context. Robust smart practices are adaptable to various conditions, have many operational features, and can employ similar but diverse ways to achieve their goals. They should have the characteristics of a model.

\section{The good practice description should provide insight}

The good practices need to provide insight into the factors or conditions that determine what is going on in the practice. Presenters of a good practice need to go beyond the description and address the 'why' question.

\section{The good practice should be clearly described}

The good practice has to be described in a rich, detailed way, in line with what Geertz (1973) has called 'thick description.' This description must allow the reader to understand in enough detail the way things are working in that particular situation.

\section{The good practice should be presented in a collegial way}

The authors of the good practices should address the audience as colleagues and fellow professionals, inviting them to think along (using the understandings and insights offered) to 
link the presented experiences and knowledge to their own professional context and situation. The linking implies interpretation and translation to one's own context, working conditions, imagining and hypothesizing ways to transfer the insights to one's own practice. As such, the basic message of the good practice is a call for dialogue between professionals, for sharing their understanding of their practices, and for inviting others to join the thinking in order to take the growing understanding a step further.

For the acceptance of good practices, Kelchtermans and Ballet (2009) also mention the importance of the source of the good practice. The authority of the source influences the acceptance.

\section{Applying good practices: 'translating to own context'}

Proven through rigorous research is not a criterion for a good practice. That would be nearly impossible to do for most teachers of good practices because of the complexity and the resources needed for such research. The context of the practice is also a major issue in the generalization of such research. It means that a good practice usually cannot be copied. However, the educational design of the good practice or elements of it can be inspiring. In order to draw lessons from experiences or insights from colleagues, practitioners need to translate a good practice into their own local situation (Kelchtermans \& Ballet, 2009). These practices had to be analyzed and interpreted with their own context in mind (Fullan \& Stiegelbauer, 1991; Hopkins, 2001). The premise is that good and comprehensive information (e.g., in the form of a good practice) as such will lead to educational innovation. It is certainly not tenable that the example will result in a desirable change in practice (Van den Berg \& Vandenberghe, 1995).

More specifically: one aims to be useful (for one's own context) and feasible (in one's own context). Teachers listen to innovation proposals mainly from a perspective of usability for their own practice. Kelchtermans and Ballet (2009) mention this support as a critical success factor for the effectiveness of good practices. This support can take various forms, such as imbedding the application of a good practice in a renewal project, working in a team of likeminded colleagues, or being part of a renewal policy of the institute. Honors programs typically have the advantage of often being laboratories of innovation (Wolfensberger, van Eijl \& Pilot, 2004; 2012).

\section{Different types of impact of good practices}

The researchers of good pedagogical practices, Kelchtermans and Ballet (2009), distinguish three usage variants of good practices:

\section{Superficial use}

Tips, methods, and supplied materials are taken over without applying the practical examples as a whole and without really changing the views of those involved. This variant is most common.

\section{Adoption}

In this variant, the good practice is taken over almost integrally and even copied in a teacher's own practice. Adoption can, however, become imitation when one starts acting differently without changing one's own insights and opinions. It is more about 
superficial implementation: one takes over a form without a thorough understanding of the content. In that case, it is unlikely that the renewal will be implemented sustainably.

\section{Integration}

In the third variant, the good practice is analyzed deeply and thus adapted to the specific local context and / or characteristics of those involved. In the research mentioned, this often leads to teachers trying to attune the working conditions in the school to the content of the good practice.

\section{Good practices can bring a change in view on education}

Taking note of a good practice can work as an eye-opener and can also change the frame of reference of the teacher involved. According to Kelchtermans, Ballet, Peeters \& Verckens (2008), this can have different effects on the views of the teachers involved.

\section{Confirmation of own views}

Taking note of a good practice and the underlying vision can lead to a confirmation of one's own views by recognizing one's own vision in the example. This can give the teacher involved a good feeling because he or she is meeting teachers who are on the same 'road.'

\section{Extension of existing views}

A good practice can give a new view on an approach of an educational practice, which can give an expansion of the teacher's existing frame of reference.

\section{Development of micro-instructional policy}

By attempts to introduce a good practice in the teacher's own context, some respondents became strongly aware of the need to think and act in a micro-instructional policy and strategic way (Kelchtermans \& Ballet, 2009). This is particularly important if it is an inter- or multi-disciplinary project or a project at the level of a study program or institute. These teachers develop strategies to convince their colleagues and school leaders to join the project, among other things. They anticipate different structural and organizational conditions that could complicate the implementation and should therefore be addressed in a targeted manner, if one wants to start using the good practice.

\section{Rejection}

A fourth pattern is distinguished: the (immediate) rejection of the good practice. This was the case when participants in the research of Kelchtermans et al. (2008) experienced a big and insurmountable difference between the conditions and views in the proposed good practice and their own work context and personal interpretation framework.

\section{Transfer in honors: 'Maybe this is not new for another, but in my education it is'} In a recent research project, Otto, de Jong and Zunderdorp (2018) interviewed teachers of one university (Utrecht University, The Netherlands) about the transfer (or transition) of honors innovations to other educational programs. This university has an explicit policy to apply successful innovations in honors education into the regular programs. The rector magnificus of Utrecht University (Kummeling, 2018) declared, when presenting the Honours Teacher of the Year Award 2018: 'Honors programs are vital to our university. Not only are these hugely beneficial to the students who have taken them, but they also serve a vital 
experimental function for the university: a space where teachers can test and hone pedagogical ideas before deploying these ideas in the regular programs. A small investment in the few for the great benefit of the many.'

A goal of the research project of Otto et al. was to collect data about the transfer of honors education to regular education and to find out whether an additional policy of the university was necessary. The authors interviewed 10 persons in three honors programs: among them were a member of the council of the department from each program, an honors director, and one or more honors teachers. The three honors programs differed in size, type of organization, and frequency of pedagogy transfer.

The respondents said that they considered their honors programs as laboratories of change because they could try out new educational methods and content with the honors students. For a minority of the respondents, the transfer of programs was part of the purpose of a 'laboratory of change.' The authors mention many common elements in their honors programs experiments. Elements mentioned were: 'stimulating personal development of the students' and 'to direct their own study' and 'to work with real life cases.' In addition, interand multi-disciplinary study were often mentioned, as well as the offering of new content. What was experienced as new was different, depending on their frame of reference and the context of the respondents. As one respondent expressed: 'maybe this is not new for another, but in my education, it is.'

The respondents said that it was difficult for them to see if transfer actually took place. In their opinion, a transfer of an honors good practice has a good chance to succeed if it solves a problem in the regular program. A culture that encourages innovation helps, too. If honors teachers have an extensive network within their department, it will help the spreading of innovations. Some respondents said that transfer of honors good practices to the regular program can fail because the attitude of regular students is less active than that of honors students. Other respondents did not agree with that view, saying that regular students also like more challenging education. In all cases, the teachers could realize the transfer because they know where an honors good practice matches with the regular program. The respondents considered the visibility of honors innovations as crucial for transfer. The authors have some recommendations to enhance transfer of honors innovations. For the honors teachers, it will be to work together with colleagues and share your experiments with others both inside and outside the institute. For the honors directors, it will be to invest in the visibility of honors good practices, encourage innovative teachers, and involve innovative teachers in curriculum changes.

In earlier studies, Wolfensberger, van Eijl, and Pilot (2004, 2012) already report spin-off effects of honors programs for regular programs. Spin-off effects were found in the content of courses, the pedagogy, and the structure of an educational program.

Transfer of good practices is not always a visible process but a process of 'silent transfer.' Sometimes, teachers take notice of good practices and may decide to do something with them. Perhaps they get ideas or change their frame of reference. In previous projects (van Eijl \& Pilot, 2016; Coppoolse, van Eijl \& Pilot, 2014), we encountered examples of transfer of good practices of teachers who had read a good practice in one of the publications and 
contacted the teachers involved. These contacts inspired them to use elements of that innovation in their newly designed honors program.

\section{Educational principles of honors education: different views}

Good practices in honors education can be seen as illustrations of the principles of honors education. Considering examples in relation to principles can, according to van Parreren (1970), result in (more) insight into these principles. This insight makes the acquired knowledge agile, so that it can also be applied more easily in a different context. This is essential for the transfer of good practices. But what are the pedagogical principles in honors education?

Principles of honors education are expressed in different ways by different authors. Organizational characteristics and educational (pedagogical) principles are sometimes closely linked. First, a brief overview of the characteristics and principles of both American and Dutch honors programs is presented here. Then, different views from some researchers of honors education follow. This section ends with a series of keywords for honors that represent the different views.

7.1 Basic characteristics and key points of a fully developed honors program (NCHC, U.S.A.) The definition of honors education by the National Collegiate Honors Council (NCHC, 2013) highlights many educational aspects: 'in-class and extracurricular activities that are measurably broader (multi- and interdisciplinary learning), deeper (learning in depth), or more complex than comparable learning experiences typically found at institutions of higher education.' Also service learning, leadership, experiential learning and learning communities are mentioned as important aspects of honors education. Honors experiences include a distinctive learner-directed environment and philosophy, provide opportunities that are appropriately tailored to fit the institution's culture and mission, and frequently occur within a close community of students and faculty. In most cases, the honors community is composed of carefully selected teachers and students who form a cross- or multi-disciplinary cohort dedicated to achieving exceptional learning and personal standards. In universities and colleges, the credit points refer to the number of contact hours per week in class for one term. Students are generally expected to spend two to three hours outside class studying and doing homework for every hour spent in class.

\subsection{Ten key points for honors programs (Netherlands)}

For Dutch honors programs, ten key points for honors programs were formulated by van Eijl, Pilot, and Wolfensberger (2010). The honors pedagogy focuses on excellence with challenging assignments of a high content level and is diverse in design with an emphasis on 'discovery learning.' Attention is being paid to leadership, as well as to communicative and social skills. Excellent performance is valued, and there is plenty of room for new ideas and creative initiatives from students, for which facilitation is provided. The program pays a lot of attention to feedback from teachers and fellow students on individual talent development and personal development. Students also stimulate each other through team work, honors communities, and extra-curricular activities. The work load of a course in Dutch higher education is expressed in ECTS, an acronym for European Credit Transfer and Accumulation System. A full study year normally consists of 60 credits. One ECTS (often abbreviated to EC) is, in The Netherlands, an equivalent of 27.5 hours work by the student, including classes, 
other relevant meetings, homework, group work, and assessment.

\subsection{The three pillars of honors pedagogy}

In search of a pedagogy for honors education, Wolfensberger (2012), after literature review and interviews with experienced honors teachers, formulated three pillars of honors pedagogy. These pillars are: creating community, enhancing academic competence, and offering freedom.

To become intrinsically motivated, three psychological needs of students in (higher) education have to be met, which are, according to Ryan \& Deci (2000), autonomy, competence, and relatedness. The three pillars of honors pedagogy, as formulated by Wolfensberger, meet these psychological needs. Because honors students prefer autonomy to make their own choices, they appreciate an autonomy-supportive teaching style characterized by relatedness and a good balance between autonomy and structure (Pintrich \& De Groot, 1990; Reeve, 2009; Sierens, Vansteenkiste, Goossens, Soenens \& Dochy, 2009). In a literature study, Kingma, Heijne-Penninga, and Wolfensberger (2018) elaborate on the autonomy-supportive teaching style and mention three clusters of teaching strategies that can foster the offering of freedom:

- Strategies that create space for students' questions, choices, and initiatives' scaffolding

- Strategies that foster a sense of excitement and experimentation

- Strategies that treat honors students as 'junior colleagues' in research and education (activities).

The psychological relatedness resonates with the notion of a sense of community. Autonomy is clearly related to (a certain degree of) freedom. In her 'integrative model for excellent performance,' Wolfensberger (2011) emphasizes that talented and motivated students need 'bounded freedom.' This means that students must be given the space to develop their own passion, to be able to follow their interests, to be able to make their own plans, and to meet people. But, the teacher also has to set limits to channel creativity because choices have to be made, decisions taken, and deadlines met.

\subsection{Characteristics of practice-oriented honors programs}

In universities of applied sciences in The Netherlands, there are quite a number of practiceoriented honors programs. In these programs, a complex problem in the professional work field is central in the student's work. From her experience and research with practiceoriented honors programs in Rotterdam University of Applied Sciences, Lappia et al. (2014) and Lappia-Van Es (2015) name five characteristics in which 'Learning to innovate' is a key issue.

\section{Multi-disciplinary practice}

Students work on a real, but wicked, multidisciplinary problem with students of different disciplines. The problem cannot be solved with a routine approach and requires development of new knowledge and higher-order learning.

\section{Authentic learning environment}

The supervising teachers, in collaboration with partners from professional practice and researchers, realize a challenging learning environment. This learning environment 
requires 'situated learning'; that is, learning in a context that is similar to the situation in which graduates in the professional field have to work on innovations.

\section{Professional excellence}

The goal that is being pursued and assessed is that students learn to innovate and to contribute to innovative solutions for practical issues. Weerheijm \& Miltenburg (2017) describe professional excellence as a generic learning objective of an honors program.

\section{High expectations}

The learning environment and the multi-disciplinary problem mentioned above are very suitable for students who want and are able to do more than what the regular program offers. Honors students ask for challenges in the form of complex tasks and high expectations, coupled with more autonomy and space for their own initiatives (Scager, Akkerman, Pilot \& Wubbels, 2013). Students and teachers are expected to have a growth mindset instead of a fixed mindset (Dweck, 2006), and teachers see practice-based honors programs as a means to stimulate students' abilities, creativity, and task commitment to an above-average level.

Honors students are mainly recruited and selected on the basis of motivation. Teachers search for teaching strategies to stimulate the passion of honors students to tackle the practical problem.

\section{Learning work community}

Because, in honors, much emphasis is placed on autonomy and self-directed learning by students, it is very important that students and teachers build up a bond of trust and form a close community. This learning community is an important part of an authentic learning environment and forms the portal for the various communities of practice (Wenger, 1998) that students are involved in after their studies.

\subsection{Relationship between challenge and other characteristics of honors}

Scager, Akkerman, Pilot. and Wubbels (2013) investigated the relationship between challenge and other characteristics of honors in six honors courses of a liberal arts and sciences college of Utrecht University, The Netherlands. They used focus interviews guided by the story-line method and analyzed course materials and audio-recorded classes to describe how challenge was established.

Students appeared to experience the highest level of challenge when three factors occurred simultaneously: autonomy, complexity, and high expectations of teachers. Autonomy became visible in the choice of assignments, control over achievement, student responsibility, non-directive feedback, and openness to student initiatives; all of these factors match the descriptions of autonomy-supportive teaching behavior (Reeve, Bolt \& Cai, 1999). Complexity referred especially to the novelty (and abstractness) of the course material, high level of questions, and the requirement for critical thinking. High teacher expectations had a strong influence on the perceived level of challenge. Important here were the teacher's reputation, the announcement of challenge (the difficulties students were expected to face), the teacher as co-learner, the need for active participation, and the need to prepare for class. The challenge level varied between courses but also between different activities within a course. 


\subsection{Circle of talent development}

In 2015-2016, van Eijl and Pilot (2016) did a project, 'The Honours Experience,' in which they interviewed forty honors students of different honors programs in The Netherlands about their learning experiences in their honors programs. They asked questions about what challenged them, about their ups and downs and how they had overcome their dips, what inspired them, and what their process of talent development involved. In addition to the student interviews in this project, they also interviewed eight of the teachers that were involved in the coaching of these students. The results were published in a book that provides a common thread in their findings and the sections linking these to research literature on talent development. As a framework for the analysis of the student learning experiences, they used the Circle of Talent Development (van Eijl \& Pilot, 2016; van Eijl, Pilot, Gelink \& Dibo, 2017) (Figure 1).

\section{Figure 1: Circle of Talent Development}

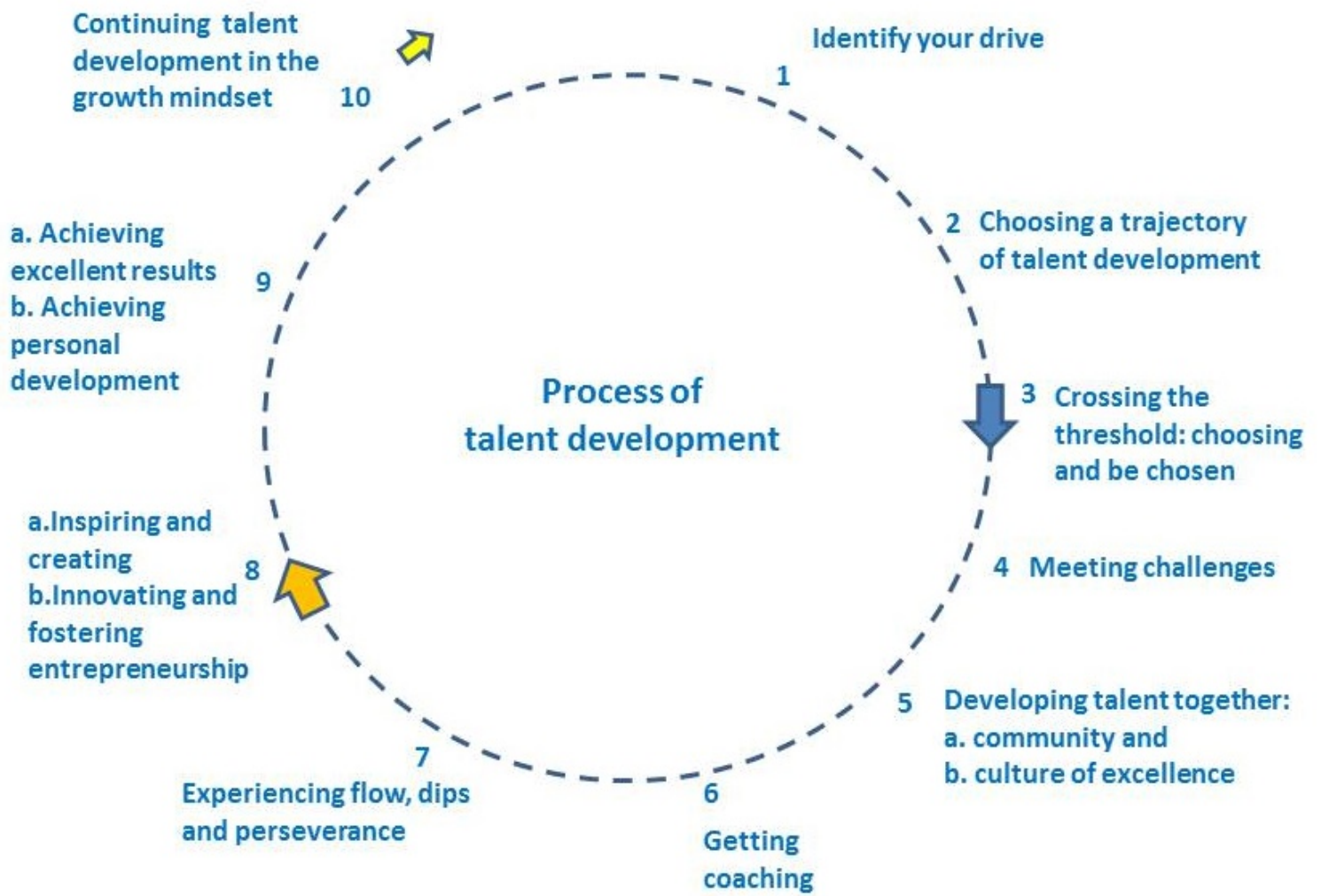

Source: van Eijl \& Pilot, 2016, p. 13

The Circle of Talent Development starts (step 1) with the identification of a student's drive to do something more or different from the regular program. This can lead to step 2 , the choice for a trajectory of talent development. An honors program is such a trajectory. Step 3 reflects the admission procedure, where students have to pass a selection procedure to be admitted to the honors program. The challenges (step 4) students meet in the program are of central importance for their learning. This can ignite their interest and get their process going of discovery learning and sometimes hard work. The student is usually not alone but works with other honors students, a teacher/coach, or outside experts. An honors community (step 5a) can develop, in which students stimulate each other in their interests 
and thinking about the challenge. Gradually, a culture of excellence (step 5b) can grow if students start striving to results that matter. Coaching (step 6) is of key importance to support the students in their study and to inspire them to make an extra effort in their work. Coaching is also important because students not only experience a flow in their work but also dips (step 7). Perseverance is sometimes necessary to keep on track in an honors activity, when it is difficult and stagnation threatens to block the process. A creative insight or an entrepreneurial type of initiative (step 8) can bring a project or other honors activity a new perspective. At the end (step 9), students can attain excellent results but also, and sometimes even more importantly, a gain in personal development. After a project or activity is completed, students may benefit from the growth mindset (step 10), which is developed or reinforced during their honors work. Altogether, this Circle of Talent Development is an organizer for important honors activities of students, but the sequence of steps 4 to 8 is not strict.

Additional information about the steps in the circle, illustrated with brief quotes from student interviews that support the framework of the circle, are given in the book 'The Honours Experience,' for which a synopsis in English is available (van Eijl \& Pilot, 2016). The steps in the circle are used in the format of good practices in this issue to give a characterization of the strengths of these practices in the experience of the teacher.

\subsection{Honors keywords as a bridge between educational principles and practice}

The educational principles and characteristics of honors programs mentioned before by different authors have a significant overlap. However, there is also a lot of variation in it. The same is true for honors programs and good practices in honors. To bridge the gap between educational principles and the practice of honors education, we have chosen a series of keywords out of the principles presented above that are recognizable in the good practices. The keywords presented below are in sequence with the steps in the Circle of Talent Development. -challenge (broader, deeper or more complex) -authentic (real world problem; realistic learning situation) -(honors) (learning) community (team work, cooperation) -inter/multi-disciplinarity -bounded freedom/autonomy (choices offered) -creativity -coaching (autonomy supportive teaching style) -(self)(critical) reflection -excellence (culture of excellence; engendering academic competence, high expectations) -personal development (personal leadership)

These are the keywords one may expect in good practices of honors programs, courses, and activities. Not all good practices will necessarily have all the keywords because different practices will have different emphases. In the good practices published in this issue, the keywords are in italics in the texts.

\section{The collection of good practices for the Dutch Honors Network}

The collection of good practices started as part of the activities of the Dutch Honors Network of honors teachers. The leading idea was that we can learn a lot from each other and 'a good example tends to be followed.' Good examples could be inspiring for other honors teachers but also for teachers in the regular programs. Each member of the network was asked to 
look around in their institution for suitable good practices. To make the good practices easily accessible for a reader, a format was developed for the description of the good practices. The good practice could be a part of an honors course, a complete honors course, or an honors program. It should be a practice that a teacher has good experiences with, that students value, and that may be inspiring for other teachers. For the format, we also consulted Eyckmans (2017) of the University of Antwerp, who had experience with a special format used to internally exchange information about their courses and the experiences with them. The format we developed in this project was tried out two times with different teachers and then modified into the present form.

The format (Appendix A) contained typical elements for a description of the practice, such as name, place in the curriculum, type of assessment, size, and length, but also why this good practice was developed (what was the original challenge for the teacher who developed it?) and the educational design (the description of the build-up of the practice, so the reader could get insight in the strength of it), experiences with the good practice, and possibilities for transfer to another educational situation. In Appendix A, the format is described. The description of the educational design (item 7) refers to the 'model' (Earl, 1983) and the 'core' (Bardach, 2011) of a good practice described in section 2. The description of the 'why' statement (item 4) refers also to section 2 (Kelchtermans \& Ballet, 2009). An e-mail address (item 2 ) is included to contact the author for additional information.

We invited teachers via the Honors Network to contribute to this project with the help of the format developed. At the start of the project, an extra effort by means of interviews with honors teachers was necessary in order to arrive at good descriptions. Some teachers contributed without interviews, only on invitation with feedback on their draft descriptions from the project leaders. After the texts of the descriptions were checked by the teachers (member check), the descriptions were published on the website of the Honors Network (mostly in Dutch). Apart from the honors teachers connected with the Dutch Honors Network, we also invited two American honors teachers with a long experience in honors education to contribute a good practice.

So, the 19 good practices in this study were the result of initiatives from member-teachers of the Dutch Honors Network and two American colleagues of NCHC. For this issue of the Journal of the European Honors Council, we selected nine good practices that we considered to be the most informative for the international readers of this journal (those including much information about the why and the how of the practices).

During the project, we used the term 'best practice,' but to avoid misunderstandings, we use the term 'good practice' in this paper.

\section{Differences and common characteristics in the good practices}

By early 2018 (a year into the project), 19 good practices had been collected. An analysis yielded the following remarkable differences and common features.

\section{Rich variety}

All good practices are very different in terms of content and form. There is apparently a rich variety of good practices in honors programs. The good practices vary from subject-specific 
to cross-curricular examples and from disciplinary to multidisciplinary. Most good practices come from universities of applied sciences because we focused mainly on this type of university (not on the research universities).

\section{Extent of the good practices are very different}

The extent of the good practices varied from three relatively short activities, five shorter courses of a couple of days, eight longer courses, projects, or trajectories of weeks or months, and two programs of a couple of years.

\section{Many common characteristics}

In addition to differences, there are also a number of common elements. Giving the students autonomy (the teachers describe this as openness) is present in (almost) all good practices presented here. We interpret this as autonomy because students were allowed to contribute a project to work on or to self-direct an activity. In all practices, the ideas of students were taken into account.

Often a real, 'authentic' problem which required a solution was the focus of student activities. This could be an assignment from the work field of an external client. Students often worked on a product that is going to be used in practice. This can be strongly motivating for them.

Intense interaction and collaboration are striking in the teams working on a project. This involves learning by presenting and discussing new knowledge, insights, and ideas. Mutual feedback often took place, as well as development of new ideas through brainstorming and interest in each other's ideas.

External assignments were often linked to multidisciplinary groups of students because more disciplines are necessary to come up with a valuable solution for a problem.

In most good practices, there is an explicit stimulus for personal development. Sometimes working on the content of a project and personal development are strongly intertwined. The teacher often has a coaching role. He or she is an inspirer, not someone who prescribes the learning experiences of the students. Expertise is sometimes obtained from outside the learning situation: either from the external client, researchers, or other experts.

\section{Analysis of the descriptions of good practices}

In the format, some elements are especially of interest for the value of a good practice to other teachers. The challenge for the teachers is to develop the core of a good practice (item 4 in the format), the educational design (item 7) and the possibilities of transfer (item 13). We will start in section 10.1 with the educational design of the good practices, which can contain a 'model' for other teachers.

\subsection{Analysis of the educational design information in the good practice descriptions}

The descriptions of the educational design vary, and each design has its own approach to fostering students' learning. Some common elements can, however, be distinguished. Remarkable is that students often have the freedom to decide for themselves on the subjects / problems to be studied and how to approach them. The idea of 'bounded freedom' is regularly a key element because students have to take care of constraints and time limits. Much learning takes place in interaction with other students, in teams, work 
groups, and / or communities. Progress in activities, new ideas but also drawbacks, are discussed in these interactions. It is striking that, in a number of good practices, multidisciplinary or international teams are mentioned as being essential. Students have to plan their activities in their own way, but, for a large project, a team of students makes a project, planning with consultations, reports, and coordination.

The scope of the activities varies greatly, from short-cycle work of a few days to long-term trajectories of (many) months for an external client.

Personal development plays an important role in many good practices. Students have to formulate their own learning objectives, practice with aspects of personal performance, and give feedback on personal performance of other students.

Regular reports of progress and the use of portfolios by students to discuss their own learning process is present in some good practices with the underlying goal of an intense learning process.

In the design, teachers typically are given a coaching role. Often, the possibility to consult external experts is provided in a project.

\subsection{Analysis of why this good practice was developed}

In the format (item 4), teachers described why they developed this good practice: what was the challenge for the teacher, and why was is designed this way?

All good practices are aimed at offering more challenge to honors students, who (in The Netherlands) often do honors in addition to their regular curriculum. The challenge they offer students varies from being more in charge of the regulation of their lives and study activities to thinking more about what they really care for in life and looking for their own goals to addressing complex wicked problems with a multidisciplinary group to working with real problems with a client and an emphasis on experiential learning. This should promote ownership of learning. The method followed is also intended to support the honors community.

Most projects are aimed at further personal and social development of students in which international cooperation, working from different perspectives, and social responsibility are key components.

Sometimes, the good practice is mainly developed by students. In some honors programs (in the social domain), students determine themselves what they will do together.

Some programs offer the opportunity to discover and further develop talents, such as critical thinking, collaboration, leadership, creativity, and giving or receiving feedback and learning from each other's ideas. Reflection on experiences and one's own actions is sometimes the key issue. This reflection then focuses on the process of cooperation and the effectiveness of the individual in it. So, students can become aware how learning can be meaningful, practical, transferable, and durable as a life-long endeavor. 


\subsection{Analysis of transfer in good practices}

Our goal of the description and publication of examples of good practices is also to promote the transfer of honors innovations to regular and other honors programs. In the format, teachers are invited to write about their experience with the transfer of their good practice to other programs and what they see as possibilities. A short impression of completed transfer items in the good practices follows below.

Every teacher of a good practice saw possibilities for transfer to other honors education or regular education. Even more important was that many transfers already took place. Six good practices have already inspired other teachers. In one example, teachers from two other universities were inspired because the good practice was published earlier in a book. The educational ideas of a couple of other good practices were used (or are intended to be used) in curriculum renewal not only in honors programs (two times) but also in regular programs (five times). To appreciate a good practice, it can be necessary to experience it, some teachers said.

Once tested and perfected in honors, another teacher said, the portfolio model could easily be transferred to other programs, strengthening teaching and learning throughout the institution. Many teachers said that transfer of elements of the good practice is a possibility. Sometimes, teachers mentioned adjustments: e.g., shortening the activity; less open and better defined projects; more workshops; a stricter timetable; and more guidance.

Conditions for transfer were specified: e.g., participants from different disciplines; complex themes; cooperation on a project; motivation of students in regular education; appreciation of challenges; extra time needed for slower students.

Besides the information from the transfer item in the format, we received spontaneous remarks from teachers who had read (some of) the good practices and mentioned that these gave them new ideas for their own teaching. This is a form of 'silent transfer' as mentioned earlier in this article.

\section{The good practices in this issue}

To illustrate the diversity and richness of good practices in this project, we selected nine good practices for publication in this issue. Seven good practices come from Dutch honors programs and two from American honors programs. These examples come from educational systems the reader may not be acquainted with. When you read the good practice, it is good to keep in mind some of the differences between the American and the Dutch higher educational systems.

\subsection{Some differences between the American and Dutch university systems}

In the USA, honors programs are usually part of a liberal arts and sciences curriculum in a higher education institution. The bachelor program lasts four years. Students can earn credits toward graduation for completing honors courses. For the honors program, students are selected on the basis of a set of admission criteria.

In The Netherlands, a university bachelor degree lasts three years (in research universities, where students are eligible with a six year high school program) or four years (universities of applied sciences, where students are eligible with a five year high school program). The master program is one or two years. The students are selected for the honors program on the basis of a set of admission criteria. The honors program is often an extra curriculum 
parallel with the regular curriculum. Most honors programs are during the bachelor degree, but some are in the master program (van Ginkel, van Eijl, Zubizarreta \& Pilot, 2012). The regular bachelor curriculum is mostly discipline oriented, e.g. chemistry, pedagogical sciences, medicine, or law. However, some bachelor curricula are of the 'liberal arts and sciences' type. In most honors programs, students do not earn extra credits for their regular bachelor or master diploma. However, they earn extra credits necessary for their honors diploma. Some honors programs are inter- or multidisciplinary or have elements of interdisciplinarity.

\subsection{Nine examples of good practices in this issue}

To illustrate the rich diversity of the good practices in this project, we choose nine of the 19 examples for publication in this issue of JEHC. These examples come from different universities and different disciplines and have different educational approaches. We preferred honors activities and courses above whole curricula because it is easier to make use of a good practice in a small part of the honors program. Teachers had to be willing to spend time to edit their good practice description for a note in this issue.

The nine examples of good practice in this issue of JEHC are:

1. 'Personal leadership' is an example of an honors course where personal development is the focus.

2. 'Honors project within the regular minor program' shows that it is possible to combine a regular minor program with meaningful honors activities for deepening the content with projects and assignments from the professional field.

3. In 'Innovation labs,' students from different disciplines work together in multidisciplinary groups to tackle an authentic and wicked problem from professional practice.

4. In 'Writing a book,' honors students are stimulated to develop $21^{\text {st }}$ century skills, including communication and cooperation competencies. In this program, students are challenged to write a (science) book for the regular curriculum or design a website on a subject that is relevant for their discipline during one academic year.

5. The 'Facilitator training for the Saxion Top Talent Innovation Days' is a training for honors students and teachers to prepare them for guiding groups of students in projects with authentic problems.

6. 'Presentation student's personal learning journey' is an honors activity where students complete their first year's honors program with a presentation in a small theatre for family and friends.

7. The 'International Honors Summer Institute on Holocaust Remembrance' is a twoweek summer school for an international group of honors students with visits, projects, and teamwork.

8. 'Improving and assessing honors student learning with learning portfolios' presents the learning portfolio as a tool for helping students to develop the skills and habits of meaningful critical reflection.

9. In 'Scaffolded, Collaborative Project-based Learning (PjBL),' students confront realworld challenges, collaborate to create solutions, and present their results in a public setting. In PjBL courses, the project is at the core of the curriculum, involving an indepth inquiry and requiring revisions and reflections of the artifacts developed. 


\subsection{Good practice in relation with the Circle of Talent Development}

We asked the teachers who publish their good practice in this issue how they rate their good practice in relation to the steps in the Circle of Talent Development (see Appendix B). This rating can give the reader an impression of the strengths of a particular good practice. We posed this question in relation to each of the 10 steps in the Circle of Talent Development. The question was: How important are the activities of the Circle of Talent Development in your good practice description '....'? Please, give each step in the circle a score: $+=$ somewhat important; $++=$ moderately important; $+++=$ very important; - = not applicable or irrelevant.

Answers were compiled and visualized in Figure 2.

With a mean of 2.9, 'Meeting challenges' was the highest rated step of the circle, closely followed by 'Experiencing flow, dips, and perseverance'(2.8), 'Results,' 2.7, 'Getting coaching,' 2.6, 'Continuing talent development in the growth mindset,' 2.6, and 'Developing talent together,' 2.4. The first three steps had a lower score: 'Identify your drive,' 2.2 ('moderately important'), 'Choosing a trajectory of talent development,' 1.3 ('somewhat important'), and 'Crossing the threshold: choosing and be chosen,' 1.8 ('moderately important'). These scores are probably lower because these steps refer to student activities at the time when they are deciding to start an honors program. The other steps refer to activities during their honors courses. The published examples are all honors courses or honors activities.

Figure 2: Circle of Talent Development with total scores of the nine good practices related to each step: total number of ' + ' and the average score.

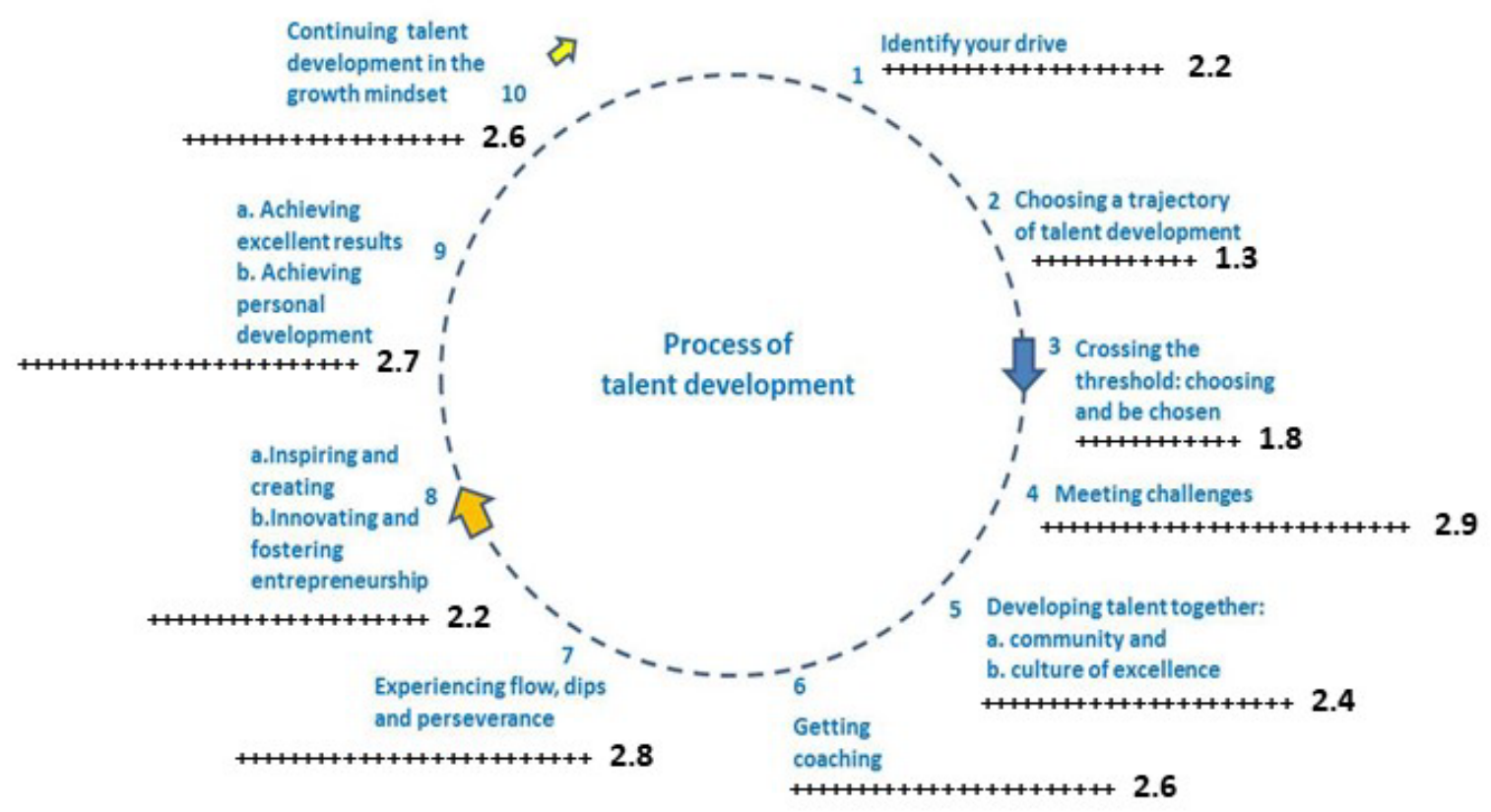

We added a second question for a verbal statement about the attractiveness of a good practice for other teachers: What makes your good practice attractive for other teachers? 
Some teachers emphasized that the learning process of the student(s) also interacts with their own learning process.

At the end of each good practice in this issue, the results of the two questions are presented.

In a third question, we asked the authors where they are interested in: What aspects make other good practices attractive for you? A summary of their answers in two parts is presented below.

(a) Innovative aspects which teachers can use and adapt to their own specific situation. Aspects which could facilitate/challenge students to get the best out of themselves, and strategies and methodologies that focus on deepening and extending student learning. Good practices which help students gain content expertise, but also help students to make connections between different disciplinary ways of thinking, help them to explore divergent ideas, help nurture their creativity, invite them to take risks, and reinforce their excitement for learning.

(b) Aspects you can learn from as a teacher.

A quote of one teacher gives a nice summary of all teachers' answers: 'l'd like to see more good practices that can make a difference. As a teacher, I am always inspired by strategies and methodologies that focus on deepening and extending student learning. I am attracted to active learning approaches that engage students in more than knowledge, competencies, outcomes, or grades. I gravitate toward teaching that, of course, helps students gain content expertise but also helps students make connections between different disciplinary ways of thinking, helps them explore divergent ideas, helps nurture their creativity, invites them to take risks, and reinforces their excitement for learning.'

\section{Conclusions}

The leading questions in this project led to the following conclusions.

\section{1) Is it possible to collect good practices in honors education via an honors network?}

It turned out to be possible to collect good practices in honors education by means of the Dutch Honors Network, but a large investment in time and effort was necessary to get the descriptions of the good practices according to the format that was developed. First, a format was developed for description of a good practice. This format was tested in two tryouts, via the Dutch Honors Network teachers who were invited to contribute to this project and fill in the format. At the start of the project, an extra effort by means of interviews with honors teachers was necessary in order to arrive at good descriptions. Some teachers did this on invitation with feedback on their draft description from the project leaders.

\section{2) What are the characteristics of good practices in honors education as described by their teachers?}

The 19 good practices are very different in terms of content and form. There is apparently a rich variety of good practices in honors programs. The good practices vary from subjectspecific to cross-curricular examples and from disciplinary to multidisciplinary. 
Also, the extent of the good practices is very different: short activities of some hours, shorter courses of a couple of days, longer courses, projects, or trajectories of weeks or months, and honors programs of some years.

Most good practices had many characteristics in common: giving the students autonomy; focus on a real, authentic problem requiring a solution; intense interaction and collaboration in the teams working on a project; and an explicit stimulus for personal development. A broad range of issues that are relevant and inspiring for us in this project focused on the possibilities to enhance the quality of honors and regular education by describing, analyzing, and making available inspiring activities about: 'offering personal development,' 'to develop creative possibilities,' 'learning to work in a multidisciplinary group on a complex project,' and 'to further personal and social development of students in which international cooperation, working from different perspectives and social responsibility.'

A key point in the educational design of the good practices in honors compared with the regular curricula was more freedom for students to decide what they want to work on, how they will work on something, and with whom they will work on it. But, it is a freedom within certain limits (bounded freedom).

Other important themes mentioned were: 'often working on a real problem is put central, sometimes in cooperation with an external client,' 'offering space for personal development always comes forward as important,' and also 'the coaching role of the teacher' and 'the possibility to consult experts.'

\section{3) Do teachers of these good practices think these can be applied in other educational programs?}

The analysis of the 19 good practices shows that all teachers involved thought a form of transfer of their good practice to another program is possible. In seven good practices, transfer has already been realized or is already underway, usually but not always within the institution itself. However, some teachers said that transfer is only possible under appropriate conditions. For example, because there should be a multidisciplinary target group of students. Or because it requires schedules that offer the possibility for students to join both the regular and the honors program. Scheduling is also an issue when students from different programs are participating.

There are also signs of 'silent transfer,' in which a good practice is read and valued by someone, but the original teacher does not hear anything about it being applied.

\section{Discussion and reflection}

A simple idea of how a good practice works is that it sells itself. However, in this project, we discovered a lot of good practices that were unknown to us and many others. So, describing good practices, and showing different perspectives of honors education in a model to order good practices, may be an important step to enable innovation. However, we also think that more effort is necessary to cover different disciplines and types of honors approaches.

Interactions in workshops, conferences, and personal contacts can deepen the understanding of a good practice and lead to new ideas. 
Not all good practices are interesting for teachers. But, when there is a need for course and curriculum renewal in an institution, teachers have much interest in good practices elsewhere that can help in the renewal process. In many good practices, the focus is on challenging students. This may be the result of a widely felt need for more challenges in Dutch higher education some 10 years ago. This stimulated the development of honors education, but it is still an issue in regular education nowadays. This makes these good practices very relevant today.

In the project, we used the term 'good practices' for 'a piece of honors education that functions, in the opinion of the teacher involved, so well for the students that it may be an inspiring example for others.' Bardach (2011) discusses the use of the term 'best practice' in policy analysis. He proposes that a 'promising practice' can be field tested and investigated intensely to arrive at a 'field tested best practice' or even a 'research validated best practice.' In the same way, as resources are available, it is relevant to do research on the good practices and their possibilities for transfer described in this project. This can lead to new insights in the relations between these practices and the theories and principles of honors education that we described in this paper. However, most teachers do not describe their practices in terms of underpinning theories or research evidence. This is what we also saw when we collected the good practices in this study. Therefore, we added a theoretical framework by using keywords and the model of the Circle of Talent Development (Figure 1).

\section{Possibilities for follow-up}

This project showed the richness of successful innovations in honors education. The good practices have to be communicated and discussed more widely in the coming years to come to a full impact of their potential. At the same time, the scope of the good practice project can be enlarged. In North American and European countries, many good practices are present but not yet well known. The description and exchange of good practices gives possibilities to strengthen the concept of honors and to grow to a greater awareness of the value of honors education for innovation in both honors and regular programs. It might also inspire research into the characteristics and effects of these good practices. This can contribute to a further development of a Science of Honors Education (Jones, 2016).

\section{References}

Bardach, E. (2011). A Practical Guide for Policy Analysis: The Eightfold Path to More Effective Problem Solving. Thousand Oaks, CA: Sage.

Coppoolse, R., Eijl, P.J. van \& Pilot, A. (2014). Hoogvliegers, ontwikkeling naar professionele excellentie. [High flyers: development to professional excellence) Rotterdam: Rotterdam University Press van Hogeschool Rotterdam. Available online:

https://www.researchgate.net/publication/305215310 Highflyers development towards p rofessional excellence

Dweck, C.S. (2006). Mindset, the new psychology of success. New York: The Random House Publishing Group. 
Earl, F.A. (1983). The art and craft of course design. London: Kogan Page. Available online: http://tonyearl.curriculumdesignhe.eu/

Eijl, P.J. van, Pilot, A. \& Wolfensberger, M.V.C. (2010). Talent voor morgen. [Talent for tomorrow] Groningen: Noordhoff Uitgevers.

Eijl, P.J. van \& Pilot, A. (2016). The honours experience, talent development through the eyes of honours students (synopsis). Rotterdam: Hogeschool Rotterdam Uitgeverij. Available online:

https://www.researchgate.net/publication/305215269 The honours experience talent de velopment through the eyes of honours students synopsis

Eijl, P.J. van, Pilot, A., Gelink, V. \& Dibo, N. (2017). Promoting talent development in honours: The Honours Experience. Journal of the European Honors Council, 1(1), 9 (p. 1-11). https://doi.org/10.31378/jehc.43

Eyckmans, M. (2017). Personal communication about the format of good practices at Antwerp University.

Fullan, M. \& Stiegelbauer, S. (1991). The new meaning of educational change. New YorkLondon: Teachers College Press.

Geertz, C. (1973). The interpretation of cultures: Selected essays. New York, NY: Basic Books.

Ginkel, van S.O. , Eijl, P.J. van, Zubizarreta, J. \& Pilot, P. (2012). Honors in the Master's: A New Perspective? Journal of the National Collegiate Honors Council, 13, 2, 265-278. Available online:

https://www.researchgate.net/publication/50206124 Honors in the Master\%27s A New Perspective

Hopkins, D. (2001). School improvement for real. London: Routledge.

Jones, B. (2016). Toward a science of honors education. Journal of the National Collegiate Honors Council, 17, 1, 307-333. Available online:

https://digitalcommons.unl.edu/nchcjournal/516/

Kelchtermans, G., Ballet, K., Peeters, E., Verckens, A. \& Piot, L. (2008). Goede praktijkvoorbeelden als hefboom voor schoolontwikkeling - identificatie van determinanten en kritische factoren. [Good practices as leverage for school development - identification of determinants and critical factors.] Koepelrapport OBWPO 04.04. Leuven: Centrum voor Onderwijsbeleid en -vernieuwing. Available online: http://pedagogischestudien.nl/download?type=document\&identifier=616408

Kelchtermans, G. \& Ballet, K. (2009). Goede praktijkvoorbeelden: een goed middel tot professionele ontwikkeling. [Good practices: a good tool for professional development] Paper VELON-VELOV congress, Gent. 
Kingma, T., Heijne-Penninga, M. \& Wolfensberger, M.V.C. (2018). Offering freedom as a teaching strategy for honors students. Journal of the European Honors Council 2(1), 5 (p. 15). https://doi.org/10.31378/jehc.7

Kummeling, H. (2018). Honours Teacher of the Year Award 2018. Available online: https://www.uu.nl/en/news/dr-adri-thomas-wins-honours-teacher-of-the-year-award-2018

Lappia, J., Weerheijm, R. Pilot, A. \& Eijl, P.J. van (2014). Gesprekken met honoursstudenten over persoonlijke en professionele ontwikkeling. [Conversations with honors students about personal and professional development]. Rotterdam: Hogeschool Rotterdam Uitgeverij. Available online:

https://www.researchgate.net/publication/273762380 Gesprekken met honoursstudente $\underline{\mathrm{n} \text { Over persoonlijke en professionele ontwikkeling }}$

Lappia-van Es, J.H. (2015). Intelligent interveniëren: docentprofessionalisering voor honoursonderwijs. (doctoral dissertation). [Intelligent intervention: teacher professionalization in honors education]. Rotterdam: Hogeschool Rotterdam Uitgeverij. https://doi.org/10.3990/1.9789036540094

National Collegiate Honors Council (2013). Definition of honors education. Available online: https://www.nchchonors.org/uploaded/NCHC FILES/PDFs/Definition-of-Honors-

Education.pdf

Otto, I., Jong, N. de \& Zunderdorp, K. (2018). 'Misschien is dit voor een ander niet zo nieuw, maar in mijn onderwijs wel'. [Maybe this is not new for you, but in my education it is'].

Th\&ma, 3, 73-78.

Parreren, van C.F. (1970). Leren op school. [Learning in school] Groningen: Wolters Noordhoff.

Pintrich, P. R. \& De Groot, E. V. (1990). Motivational and self-regulated learning components of classroom academic performance. Journal of Educational Psychology, 82(1), 33-40. https://doi.org/10.1037/0022-0663.82.1.33

Reeve, J. (2009). Why teachers adopt a controlling motivating style toward students and how they can become more autonomy supportive. Educational psychologist, 44(3), 159-175. https://doi.org/10.1080/00461520903028990

Reeve, J., Bolt, E. \& Cai, Y. (1999). Autonomy-supportive teachers: How they teach and motivate students. Journal of Educational Psychology, 91, 537-548.

Ryan, R. M. \& Deci, E. L. (2000). Self-determination theory and the facilitation of intrinsic motivation, social development, and well-being. The American Psychologist, 55(1), 68-78. https://doi.org/10.1037110003-066X.55.1.68 
Scager, K., Akkerman, S.F., Pilot, A. \& Wubbels, T. (2013) How to persuade honors students to go the extra mile: creating a challenging learning environment. High Ability Studies, 24(2), 115-134. https://doi.org/10.1080/13598139.2013.841092

Sierens, E., Vansteenkiste, M., Goossens, L., Soenens, B. \& Dochy, F. (2009). The synergistic relationship of perceived autonomy support and structure in the prediction of self-regulated learning. J. Educ. Psychol. 79(Pt 1), 57-68. https://doi.org/10.1348/000709908X304398

Van den Berg, R. \& Vandenberghe, R. (1995). Wegen van betrokkenheid. Reflecties op onderwijsvernieuwing. [Ways of involvement: Reflections on educational innovation] Tilburg: Zwijsen.

Weerheijm, R. \& Miltenburg, I. (2017). Powerful learning environments. Rotterdam: Hogeschool Rotterdam Uitgeverij. Available online:

https://www.hogeschoolrotterdam.nl/onderzoek/projecten-en-publicaties/pub/powerfullearning-environments/b94b5125-556c-4e29-895e-731acf0b434f/

Wenger, E. (1998). Communities of practice. Learning, meaning and identity. New York, Cambridge University Press.

Wolfensberger, M. V. C. (2012). Teaching for Excellence. Honors Pedagogies Revealed. Münster: Waxmann. Available online:

https://www.researchgate.net/publication/305411691 Teaching for excellence honors pe dagogies revealed

Wolfensberger, M.C.V. (2011). Excelleren in het hoger onderwijs en samenleving: een integratief model rondom uitmuntende prestaties. [To excel in higher education and society: an integrative model of excellent performance.] Onderzoek van Onderwijs, 40(3), 44-51.

Wolfensberger, M.V.C., Eijl, P.J. van \& Pilot, A. (2004). Honors programs as laboratories of innovation: a perspective from the Netherlands. Journal of the National Collegiate Honors Council, 5(1), 115-142. Available online: http://digitalcommons.unl.edu/nchcjournal/141/

Wolfensberger, M.V.C., Eijl, P.J. van \& Pilot, A. (2012). Laboratories of Educational innovation: honors programs in the Netherlands. Journal of the National Collegiate Honors Council, 13(2), 149-170. Available online:

http://digitalcommons.unl.edu/cgi/viewcontent.cgi?article=1359\&context=nchcjournal

For more information about good practice, in Dutch, become a member of the free Slack Honours Network.

1. Go to:

https://honoursnetwork.typeform.com/to/efHb6B

2. Then you will receive an invitation of the moderator to become a member.

3. As a member you get access to other good practices and are able to discuss them with the teachers. 


\section{Appendix A}

Format for best practice description for publication on the website of the Dutch Honors

Network.

Title: \#BP[serial number] [Title] [name institute]

[Explanation: BP stands for Best Practice. With the pre-fix '\#' and a serial number, the best practices are easily found in the files of Slack, channel Best Practices. Choose a descriptive title that is informative and preferably also appeals to the reader; state the name of your institution in brackets]

Trailer:

[Describe in a few sentences the essence of the best practice, so that the reader immediately has an idea what it is about. You may also have an appealing picture.]

Keywords:

[One or more key words add to the information of the trailer and can facilitate the search in the files on Slack website of the Honors Network]

Description of parts of the good practice

1. Name best practice:

[Title possibly with subtitle]

2. Contact persons (with e-mail):

3. Is the best practice part of which course or curriculum?

4. Why is this a best practice (What is the challenge for the teachers)?

5. Target group: [Students for whom this education is meant. Some good practices may also include teachers in the target group]

6. Size:

[How many hours or ECs (European Credit Points) requires the good practice?]

7. Design of the good practice:

[What is the structure of the best practice, i.e. the successive educational activities and the coaching? Describe this in such a way that others understand why this works so well. An example can clarify.]

8. Assessment:

[How are students assessed?] 
9. Experiences with this best practice: Insights and skills developed (Reactions from teachers and students and (evaluation) results)

10. Time requirement for teachers:

[Estimation of time necessary for this best practice, possibly to be split in first time, second time over]

11. Tips for teachers:

12. Tips for students (of other students):

13. Incorporation of honors activities in the regular program (transfer): [Is there potential for transfer to other honors programs or to regular education? Is it recommended? What kind of adjustments are desirable? Is there experience with it? If so, tell us!]

\section{Additional information (hyperlinks):}




\section{Appendix B}

\section{Questions about good practices in relation with the circle of talent development}

1) How important are the activities of the Circle of Talent Development in your good practice description 'Name good practice (Name institution)'? Please, give each activity in the horizontal row a score: $+=$ somewhat important; $++=$ moderately important; +++= very important ; - = not applicable or irrelevant

\begin{tabular}{|c|c|c|c|c|c|c|c|c|c|c|}
\hline $\begin{array}{l}\downarrow \text { Good } \\
\text { practice } \\
\rightarrow \text { Activity } \\
\text { of the } \\
\text { Circle of } \\
\text { Talent } \\
\text { Developm } \\
\text { ent }\end{array}$ & $\begin{array}{l}1 \\
\text { Identi } \\
\text { fy } \\
\text { your } \\
\text { drive }\end{array}$ & $\begin{array}{l}2 \\
\text { Choosing } \\
\text { a } \\
\text { trajectory } \\
\text { for talent } \\
\text { developm } \\
\text { ent }\end{array}$ & $\begin{array}{l}3 \\
\text { Crossin } \\
g \text { the } \\
\text { thresh } \\
\text { old }\end{array}$ & $\begin{array}{l}4 \\
\text { Meetin } \\
\text { g } \\
\text { challen } \\
\text { ges }\end{array}$ & $\begin{array}{l}5 \\
\text { Developi } \\
\text { ng } \\
\text { talent } \\
\text { together } \\
: \text { A: } \\
\text { Commu } \\
\text { nity \& B: } \\
\text { culture }\end{array}$ & $\begin{array}{l}6 \\
\text { Gettin } \\
\text { g } \\
\text { coachi } \\
\text { ng }\end{array}$ & $\begin{array}{l}7 \\
\text { Experienc } \\
\text { ing flow } \\
\text { \& dips }\end{array}$ & $\begin{array}{l}8 \\
\text { Creativi } \\
\text { ty and } \\
\text { innovati } \\
\text { on }\end{array}$ & $\begin{array}{l}9 \mathrm{~A}: \\
\text { Excellent } \\
\text { results } \\
\text { and B: } \\
\text { personal } \\
\text { developm } \\
\text { ent }\end{array}$ & $\begin{array}{l}10 \\
\text { Continui } \\
\text { ng: } \\
\text { growth } \\
\text { mindset }\end{array}$ \\
\hline $\begin{array}{l}\text { Name } \\
\text { good } \\
\text { practice } \\
\text { (Name } \\
\text { institution }\end{array}$ & & & & & $\begin{array}{l}\text { A: } \\
\text { B: }\end{array}$ & & & & $\begin{array}{l}\text { A: } \\
\text { B: }\end{array}$ & \\
\hline
\end{tabular}

2) What makes your good practice attractive for other teachers?

3) What aspects make other good practices attractive for you?

Additional information about the Circle of Talent Development in van Eijl and Pilot (2016) and van Eijl, Pilot, Gelink \& Dibo (2017). 